\title{
PERFORMANCE EVALUATION OF EQUITY FUNDS IN INDIA
}

\author{
Dr. KUSHALAPPA. S, \\ Senior Asst. Professor, \\ Dept. of MBA, \\ AIET, Moodbidri \\ RAMAKRISHNA HEGDE, \\ 2nd Year MBA, \\ AIET, Mijar, Moodbidri.
}

\begin{abstract}
:
The Indian Mutual Fund industry, though still small in comparison to the size of the Indian economy, offers Indian, and in some cases global investors, both big and small, an avenue to invest safely and securely, at a reduced cost in a diverse range of securities, spread across a wide range of industries and sectors. The managed portfolio is commonly known as mutual funds. It is an investment vehicle that pools together funds from investors to purchase stocks, bonds or other securities. An investor can participate in the mutual fund by buying the units of the fund. Each unit is backed by a diversified pool of assets, where the funds have been invested. Each investor owns shares, which represent a portion of the holdings of the fund. The primary advantage of funds is the professional management of money. Investors purchase funds because they do not have the time or the expertise to manage their own portfolios. A mutual fund is a relatively inexpensive way for a small investor to get a full-time manager to make and monitor investments. In India, a number of different types of funds offered by different companies are available. The current study focuses on the evaluation of equity funds in India. In this regard, the yearly returns of various types of equity funds have been taken into consideration. The study covers a period of five years from $1^{\text {st }}$ April 2009 to $31^{\text {st }}$ March 2014. The study is purely based on secondary data extracted from different sources. Various performance evaluation techniques are utilized like Sharpe's Performance Index, Treynor's Performance Index etc.
\end{abstract}

KEY WORDS: Mutual funds, performance, return, risk.

\section{INTRODUCTION}

Portfolio manager evaluates his portfolio and identifies the sources of strength and weakness. A portfolio, which has been evaluated through their relative merits of return and risk criteria is a managed portfolio. The managed portfolio is commonly known as mutual funds. It is an investment vehicle that pools together funds from investors to purchase stocks, bonds or other securities. An investor can participate in the mutual fund by buying the units of the fund. Each unit is backed by a diversified pool of assets, where the funds have been invested. Each investor owns shares, which represent a portion of the holdings of the fund. The primary advantage of funds is the professional management of money. Investors purchase funds because they do not have the time or the expertise to manage their own portfolios. A mutual -fund is a relatively inexpensive way for a small investor to get a full-time manager to make and monitor investments. In India, a number of different types of funds offered by different companies are available. The current study deals with performance evaluation of different type of mutual fund like Equity funds, Debt funds, Hybrid funds and Money market funds. In this regard, the yearly returns of mutual funds have been 
taken into consideration. The study covers a period of five years from $1^{\text {st }}$ April 2008 to $31^{\text {st }}$ March 2013.

\section{OBJECTIVES OF THE STUDY:}

The prime objective of this study is to evaluate the market performance of the various mutual funds in India. However in order to achieve the main objective, the following specific objectives have been framed by the researchers:

- To examine the performance of various equity funds in terms of their risk and return

- To compare the performance of various equity funds under study

- To evaluate the performance of equity funds by using various portfolio evaluation techniques
- To offer meaningful suggestions to the investors on their investment in mutual funds

\section{METHODOLOGY OF THE STUDY:}

The entire study is based on the secondary data, procured and extracted from various sources like e-source, books etc. For the purpose of analyzing the market performance of the selected funds and to test the hypothesis, various statistical tools have been used. The statistical tools like Arithmetic Mean, Standard Deviation and Coefficient of Variation. The sample size is five types of equity funds. Under each type of equity fund the top five funds have been selected.

\section{DATA ANALYSIS AND INTERPRETATION}

Table 1: Average, Standard Deviation and Coefficient of Variance of Large Cap Funds

\begin{tabular}{|l|l|l|l|l|l|}
\hline Year/Fund & $\begin{array}{l}\text { Birla Sun } \\
\text { Life Top 100 } \\
\text { (G) }\end{array}$ & $\begin{array}{l}\text { Bnp Paribas } \\
\text { Equity Fund } \\
(G)\end{array}$ & $\begin{array}{l}\text { SBI Bule Chip } \\
\text { Fund (G) }\end{array}$ & $\begin{array}{l}\text { UTI Equity } \\
\text { Fund(G) }\end{array}$ & $\begin{array}{l}\text { BOI Equity } \\
\text { Fund } \\
\text { Direct(G) }\end{array}$ \\
\hline AVG & 1.8 & 1.6 & 1.2 & 1.5 & 1.4 \\
\hline SD & 4.5 & 3.8 & 4.2 & 4.2 & 4.3 \\
\hline CV (\%) & 248.23 & 229.83 & 340.73 & 267.69 & 292.41 \\
\hline
\end{tabular}

\section{Source: Authors compilation}

Table 1 shows the fact that, among the large cap equity funds under study, Birla sun life top $100(\mathrm{G})$ Fund has the highest average return and BNP Paribas equity fund $\mathrm{G}$ has lowest coefficient of variance. SBI bluechip Fund has the lowest average return and has the highest coefficient of variance. 
Table 2: Average, Standard Deviation and Coefficient of Variance of Small and Mid Cap Funds (Equity Funds)

\begin{tabular}{|l|l|l|l|l|l|}
\hline Year/Fun & $\begin{array}{l}\text { Reliance } \\
\text { Small Cap } \\
\text { Fund (G) }\end{array}$ & $\begin{array}{l}\text { Can } \\
\text { RobecoEmer } \\
\text { g Equity(G) }\end{array}$ & $\begin{array}{l}\text { UTI Mid } \\
\text { Cap }\end{array}$ & $\begin{array}{l}\text { Lund(G) Mid Cap } \\
\text { Fund(G) }\end{array}$ & $\begin{array}{l}\text { Tata Mid } \\
\text { Cap Growth } \\
\text { Fund(G) }\end{array}$ \\
\hline AVG & 2.7 & 1.9 & 2.4 & 2.0 & 1.8 \\
\hline SD & 6.0 & 5.9 & 5.5 & 4.9 & 5.2 \\
\hline CV & 219.04 & 312.08 & 227.36 & 236.04 & 289.33 \\
\hline
\end{tabular}

\section{Source: Authors compilation}

It is clear from Table 2 that, among the small and mid cap equity funds, Reliance small cap fund $(\mathrm{G})$ has the highest average return. Tata mid cap growth fund $(G)$ has the lowest average return and Can robecoemerg equity fund has highest coefficient of variance. Reliance small cap fundhas the lowest coefficient of variance.

Table 3: Average, Standard Deviation and Coefficient of Variance of Diversified Equity Funds

\begin{tabular}{|l|l|l|l|l|l|}
\hline AVG & 0.7 & 2.5 & 1.5 & 1.0 & 1.9 \\
\hline SD & 5.3 & 4.7 & 4.8 & 5.3 & 5.7 \\
\hline CV & 707.04 & 185.44 & 317.25 & 490.05 & 298.06 \\
\hline
\end{tabular}

Source: Authors compilation

Table 3 shows that, among the diversified equity funds under study. UTI MNC fund Fund has the highest average return. TATA Equity p/e fundFund has the lowest average return and has the highest coefficient of variance. UTI MNC Fund (G) has the lowest coefficient of variance.

Table 4: Average, Standard Deviation and Coefficient of Variance of ELSS (Equity Funds)

\begin{tabular}{|l|l|l|l|l|l|}
\hline AVG & 2.2 & 2.4 & 1.6 & 1.7 & 1.7 \\
\hline SD & 7.2 & 4.4 & 4.9 & 3.8 & 4.7 \\
\hline CV & 321.28 & 182.82 & 302.54 & 229.83 & 288.04 \\
\hline
\end{tabular}


According to Table 4, among the ELSS funds under study, Axis long term equity fund $(G)$ has the highest average return and has the lowest coefficient of variance.
Principal tax savings fund $(G)$ has the lowest average return and Reliance Tax saver (ELSS) direct (G) hashighest coefficient of variance.

Table 5: Sharpe's and Treynor's Ratio for Large Cap Funds

\begin{tabular}{|l|l|l|l|l|}
\hline Fund & $\begin{array}{l}\text { Sharpe's } \\
\text { Ratio }\end{array}$ & Rank & $\begin{array}{l}\text { Treynor's } \\
\text { Ratio }\end{array}$ & Rank \\
\hline Birla sun life top 100 (G) & 0.2191 & 1 & 1.030896 & 1 \\
\hline BNP Paribas equity fund (G) & 0.215807 & 2 & 1.013199 & 2 \\
\hline SBI blue chip fund (G) & 0.093596 & 5 & 0.429807 & 5 \\
\hline UTI equity fund(G) & 0.175375 & 3 & 0.800584 & 3 \\
\hline BOI axa equity fund direct(G) & 0.148318 & 4 & 0.677798 & 4 \\
\hline
\end{tabular}

\section{Source: Authors Compilation}

As per the above table, it is clear thatunder both the techniques of portfolio evaluation, Birla sun life top 100 fund has obtained the first rank and it is followed by BNP Paribas equity fund (G), UTI equity fund(G), BOI axa equity fund direct(G) and SBI blue chip fund $(G)$.

Table 6: Sharpe's and Treynor's Ratio for Small and Mid Cap Funds

\begin{tabular}{|l|l|l|l|l|}
\hline Fund & Sharpe's Ratio & Rank & Treynor's Ratio & Rank \\
\hline Reliance small cap fund (G) & 0.317083 & 1 & 1.72577 & 2 \\
\hline Can robecoemerg equity(G) & 0.179996 & 5 & 1.058693 & 4 \\
\hline UTI mid cap fund(G) & 0.289539 & 2 & 1.77161 & 1 \\
\hline L\&T Mid cap fund(G) & 0.252831 & 3 & 1.325777 & 3 \\
\hline Tata mid cap growth fund(G) & 0.185808 & 4 & 1.041428 & 5 \\
\hline
\end{tabular}

\section{Source: Authors Compilation}

As per Table 6, under Sharpe's ratio, Reliance Small Cap Fund has received first the first rank and Can robecoemergequity $(\mathrm{G})$ has obtained the last rank. Under Treynor's ratio, UTI mid cap fund has obtained the first rank and Tata 
Asia Pacific Journals

mid cap growth fund $(\mathrm{G})$ has obtained the last rank.

Table 7: Sharpe's and Treynor's Ratio for Diversified Equity Funds

\begin{tabular}{|l|l|l|l|l|}
\hline Fund & Sharpe's Ratio & Rank & Treynor's Ratio & Rank \\
\hline Tata equity p/e fund (G) & -0.01523 & 5 & -0.09975 & 5 \\
\hline UTI MNC fund (G) & 0.362191 & 1 & 2.2275 & 1 \\
\hline Reliance equity oppor-rp(G) & 0.142527 & 3 & 0.797569 & 3 \\
\hline $\begin{array}{l}\text { Birla SL special situations } \\
\text { (G) }\end{array}$ & 0.045834 & 4 & & 4 \\
\hline HDFC equity fund(G) & 0.190352 & 2 & 0.933764 & 2 \\
\hline
\end{tabular}

Source: Authors Compilation

According to Table 7, UTI MNC fund(G)

fund $(G)$ has obtained the last rank under has obtained first rank and Tata equity $\mathrm{p} / \mathrm{e}$ both the techniques of portfolio evaluation.

Table 8: Sharpe's and Treynor's Ratio for ELSS

\begin{tabular}{|l|l|l|l|l|}
\hline Fund & Sharpe's Ratio & Rank & Treynor's Ratio & Rank \\
\hline $\begin{array}{l}\text { Reliance Tax saver (ELSS) } \\
\text { direct (G) }\end{array}$ & 0.194186 & 3 & & 2 \\
\hline Axis long term equity fund (G) & 0.355549 & 1 & 1.742416 & 1 \\
\hline Principal Tax savings fund (G) & 0.160544 & 5 & 0.759824 & 5 \\
\hline $\begin{array}{l}\text { BNP Paribas long term equity } \\
\text { fund (G) }\end{array}$ & 0.215807 & 2 & 1.061749 & 3 \\
\hline HDFC long term advantages & 0.169531 & 4 & 0.803271 & 4 \\
\hline
\end{tabular}

Source: Authors Compilation

Table 8 shows the fact that according to Sharpe ratio, Axis long term equity fund (G) is in the top position, followed by BNP Paribas long term equity fund (G), Reliance Tax saver (ELSS) direct (G), HDFC long term advantages and Principal Tax savings fund (G). As per Treynor's ratio, Axis long term equity fund $(\mathrm{G})$ is in the top position, followed by Reliance Tax saver (ELSS) direct $(\mathrm{G})$, BNP Paribas long term equity fund $(\mathrm{G})$, HDFC long term advantages and Principal Tax savings fund (G). 


\section{FINDINGS AND CONCLUSION:}

Among the large cap equity funds under study, Birla sun life top 100 (G)Fund has the highest average return SBI blue chip Fund has the lowest average return. BNP Paribas equity fund $G$ has lowest variance in its returns and SBI blue chip Fund has the highest variance in its returns. The fore it can be concluded that under large cap equity funds, Birla sun life top $100(\mathrm{G})$ is the best fund for investment.

Among the small and mid cap equity funds, Reliance small cap fund (G) Fund has the highest average return and Tata mid cap growth fund $(\mathrm{G})$ has the lowest average return. Can robecoemerg equity fund hashighest coefficient of variance and Reliance small cap fundhas the lowest coefficient of variance. Therefore, it is clear that Reliance small cap fund is the best fund among the various small and mid cap funds under study.

Under diversified equity funds, UTI MNC fund has the highest average return and Tata Equity P/E fundhas the lowest average return. UTI MNC fund has the lowest variance in its returns and Tata Equity P/E fund has the highest variance in its returns. Therefore,

Among the ELSS funds under study, Axis long term equity fund $(G)$ Fund has the highest average return and has the lowest coefficient of variance. Principal tax savings fund $(\mathrm{G})$ Fund has the lowest average return, Reliance Tax saver (ELSS) direct (G) hashighest coefficient of variance. Therefore it is true that Axis long term equity fund $(\mathrm{G})$ is the best ELSS fund. The two techniques of portfolio evaluation says that among the Large Cap Equity funds, Birla sun life top 100 fund is the best fund, among the Small and MidCap funds, Reliance small cap fund (G) and UTI mid cap fund $(G)$ are the best funds, among the Diversified funds, UTI MNC fund $(G)$ is the best fund and under ELSS funds, Axis long term equity fund $(\mathrm{G})$ is the best fund for investment.

Finally it can be concluded that the best funds suggested here does not mean that they are the best funds forever. The investor has to evaluate the performance of the mutual funds regularly so as to make his investment, a best investment.

\section{REFERENCE:}

[1] Avadhani V.A.(2011), Security Analysis and Portfolio Management, Himalaya Publishing House.

[2] Balla V. K. (2002), Portfolio Analysis and Management, Sulthan Chand and Co. Ltd., New Delhi.

[3] BhatSudhindra (2008), Security Analysis and Portfolio Management, Excel Books, New Delhi.

[4] Booie.Zvi, Kane Alex and et.al.(2006), Investments, $6^{\text {th }}$ 
edition, Tata McGraw Hill, New

Delhi.

[5] Chandra Prasanna (2008), Investment Analysis and Portfolio Management, $3^{\text {rd }}$ edition, Tata McGraw Hill, New Dehi.

[6] Fisher. E. Donald and Jordan. J. Ronald (2006), Security Analysis and Portfolio Management, Pearson Prentice Hall.

[7] Kevin. S (2008), Portfolio Management, $2^{\text {rd }}$ edition, PHI Learning Pvt. Ltd, New Delhi.

[8] Nagarajan K and JayabalG(2011), Security Analysis and Portfolio Management, New Age International.

[9] PandianPunithavathy (2004), Security Analysis and Portfolio Management, Vikas Publishing House Pvt. Ltd, New Delhi.

[10] RavindharVadapalli (2007), Mergers, Acquisitions and Business Valuation, Excel Books.

[11] Reilly. K. Frank and Brown. C. Keith (2006), Investment Analysis and Portfolio Management, $8^{\text {rd }}$ edition, Cengage Learning India Pvt. Ltd, New Delhi.

[12] Sudisudarsanam (2002), Value Creation from Mergers and Acquisitons, Pearson Education.

[13] Weston, Mitchel and Mulceril (2003), Takeovers, Restructuring and Corporate Governance, Pearson Education. 